OPEN ACCESS

Edited by:

Carmen Gianfrani,

Institute of Biochemistry and Cell

Biology (CNR), Italy

Reviewed by:

Francisco Barro,

Spanish National Research

Council, Spain

Nicolò Merendino,

University of Tuscia, Italy

${ }^{*}$ Correspondence:

Marinus J. M. Smulders rene.smulders@wur.nl

Specialty section

This article was submitted to

Nutritional Immunology,

a section of the journa

Frontiers in Nutrition

Received: 01 February 2020

Accepted: 30 March 2020

Published: 24 April 2020

Citation:

Jouanin A, Gilissen LJWJ, Schaart JG,

Leigh FJ, Cockram J, Wallington EJ,

Boyd $L A$, van den Broeck $H C$, van der

Meer IM, America AHP, Visser RGF

and Smulders MJM (2020)

CRISPR/Cas9 Gene Editing of Gluten

in Wheat to Reduce Gluten Content

and Exposure-Reviewing Methods to

Screen for Coeliac Safety.

Front. Nutr. 7:51

do: 10.3389/fnut.2020.00051

\section{CRISPR/Cas9 Gene Editing of Gluten in Wheat to Reduce Gluten Content and Exposure-Reviewing Methods to Screen for Coeliac Safety}

\author{
Aurelie Jouanin ${ }^{1,2}$, Luud J. W. J. Gilissen ${ }^{1,3}$, Jan G. Schaart ${ }^{1}$, Fiona J. Leigh ${ }^{2}$, \\ James Cockram², Emma J. Wallington ${ }^{2}$, Lesley A. Boyd ${ }^{2}$, Hetty C. van den Broeck ${ }^{3}$, \\ Ingrid M. van der Meer ${ }^{3}$, A. H. P. America ${ }^{3}$, Richard Gerardus Franciscus Visser ${ }^{1}$ and \\ Marinus J. M. Smulders ${ }^{1 *}$ \\ ${ }^{1}$ Plant Breeding, Wageningen University and Research, Wageningen, Netherlands, ${ }^{2}$ John Bingham Laboratory, NIAB, \\ Cambridge, United Kingdom, ${ }^{3}$ Bioscience, Wageningen University and Research, Wageningen, Netherlands
}

Ingestion of gluten proteins (gliadins and glutenins) from wheat, barley and rye can cause coeliac disease (CD) in genetically predisposed individuals. The only remedy is a strict and lifelong gluten-free diet. There is a growing desire for coeliac-safe, whole-grain wheat-based products, as consumption of whole-grain foods reduces the risk of chronic diseases. However, due to the large number of gluten genes and the complexity of the wheat genome, wheat that is coeliac-safe but retains baking quality cannot be produced by conventional breeding alone. $C D$ is triggered by immunogenic epitopes, notably those present in $\alpha-, \gamma-$, and $\omega$-gliadins. RNA interference (RNAi) silencing has been used to down-regulate gliadin families. Recently, targeted gene editing using CRISPR/Cas9 has been applied to gliadins. These methods produce offspring with silenced, deleted, and/or edited gliadins, that overall may reduce the exposure of patients to CD epitopes. Here we review methods to efficiently screen and select the lines from gliadin gene editing programs for CD epitopes at the DNA and protein level, for baking quality, and ultimately in clinical trials. The application of gene editing for the production of coeliac-safe wheat is further considered within the context of food production and in view of current national and international regulatory frameworks.

Keywords: gliadin, coeliac disease, ddPCR, LC-MSMS, enrichment, GlutEnSeq, T cell epitope

\section{INTRODUCTION}

Increased consumption of cereal grains has gone hand-in-hand with human development. Some 6 million years ago, as humans moved from the African forests into savannah areas, grass species with small, hard seeds became part of the human diet $(1,2)$. With the onset of agriculture during the Neolithic period, cereal grain consumption increased further, and has continued to do so right up to the present day. Flour milled from wheat (Triticum aestivum L., an allohexaploid wheat species with an AABBDD genome) became renown in Roman times for its fine viscoelastic doughs and flavorful white breads (3). Today, 220 million ha of bread wheat are cultivated annually, producing $700-750$ million tons of grain annually (4), and used in a huge variety of food products (5). 
Hippocrates, over 2,000 years ago, was credited with the phrase "Let food be thy medicine and medicine be thy food." Today, whole grain foods, including wheat, that contain all parts of the grain (i.e., the bran, starchy endosperm, and the germ) are known for their health benefits, reducing the risk of several non-communicable diseases $(6,7)$. However, wheat consumption is also associated with the development of a variety of diseases, including allergies, auto-immune responses and noncoeliac wheat sensitivity (NCWS, also called non-coeliac gluten sensitivity, NCGS) (8-10).

The most common human disease associated with wheat is coeliac disease (CD), an autoimmune reaction prevalent in $1-2 \%$ of the global population. In genetically predisposed individuals, immunogenic epitopes, found most commonly in $\alpha-, \gamma-$, and $\omega$-gliadins, trigger chronic inflammation of the small intestine. These individuals carry HLA-DQ2 (>90\% of the patients, mostly HLA-DQ2.5) and/or -DQ8 protein receptors on the surface of specific $\mathrm{T}$ cells that recognize these epitopes (11). CD leads to malnutrition and various related symptoms, ranging from bowel disorders to skin-, bone-, nerve-, and muscle-problems. CD is one of the best understood food intolerances from the perspective of human immunology and $\mathrm{T}$ cell specificity $(12-18)$. The only way to prevent $\mathrm{CD}$ is a gluten-free (GF) diet, requiring complete exclusion of wheat, barley and rye. This is very difficult to adhere to, as gluten (especially from wheat) is added to many processed food products due to its viscoelastic and binding properties (5).

Targeted gene editing, especially CRISPR/Cas9, is a tool with considerable potential for plant development and breeding $(19,20)$. With the ultimate goal of removing the immunogenic gluten epitopes from the human diet, this technology is being used in the development of wheat lines with fewer gluten genes and/or gluten genes with inactivated CD epitopes. As proof of concept, CRISPR/Cas9 technology has been used to edit $\alpha$-gliadin genes (21) as well as both $\alpha$ - and $\gamma$-gliadin genes $(22-24)$ in bread wheat. Along with $\omega$ gliadins, these gliadin types rank highest in abundance and overall immunogenicity compared with the low molecular weight (LMW) and high molecular weight (HMW) glutenins $(11,12) . \alpha$ - and $\omega$-epitopes are highly homologous (12, 16).

Gene editing of gliadin genes will initially produce plants with a mosaic of edited, deleted, and unaffected genes. Here we discuss various methods to efficiently screen and select the most promising plant lines from a gene editing program via screens at the DNA and protein level. These selection techniques are considered in comparison with their use in screening wheat lines produced using RNA interference (RNAi), in which the transcript levels of whole groups of gliadins have been down-regulated. This has resulted in lines that have strongly reduced gluten content $(25,26)$. The future application of RNAi and gene editing in wheat for reduced and/or CD-hypoimmunogenic gluten will be discussed from immunological, regulatory, food technological and safety, and consumer viewpoints.

\section{BREEDING, GENOMICS, BIOTECHNOLOGY, AND GENE EDITING OF GLUTEN GENES}

Bread wheat contains two groups of gluten proteins: glutenins and gliadings. Glutenins are comprised of HMW and LMW glutenins which can form a protein network and provide elasticity, and are thus essential for good bread dough quality (27-29). Gliadins ( $\alpha-, \gamma-$, and $\omega$-gliadins) contribute viscosity to this network. The recently published reference genome assemblies of the wheat variety Chinese Spring has enabled a good estimation of the number of genes within these gene families. In Chinese Spring, $29 \alpha$-gliadins, $18 \gamma$-gliadins, $10 \omega$-gliadins, $6 \mathrm{HMW}$-, and $16 \mathrm{LMW}$-glutenins have been provisionally annotated (30). In a separate study focusing on $\alpha$ gliadins at the homoeologous Gli-2 loci in Chinese Spring, 11, 26 , and 10 gene copies were identified on chromosomes $6 \mathrm{~A}, 6 \mathrm{~B}$, and $6 \mathrm{D}$, respectively (31). Huo et al. (32) studied the other groups of gliadins and the LMW-glutenins on chromosomes $1 \mathrm{~A}, 1 \mathrm{~B}$, and 1D. It should be stressed that other hexaploid bread wheat varieties may have different numbers of gluten genes (33). In addition, the expression levels during grain development can vary among these genes $(31,32)$ and between varieties (34).

An epitope is defined in the context of the specific human leukocyte antigen (HLA) receptor molecule (DQ2 or DQ8) that presents peptides to a $\mathrm{T}$ cell, as a peptide that can activate the recognizing $\mathrm{T}$ cell in the intolerant individual. Within gluten proteins, the epitope, a nine amino-acid peptide, is part of a larger protein fragment that is resistant to proteolytic degradation in the stomach and small intestine. Most of these resistant gluten peptides are rich in proline and glutamine amino acid residues. The glutamine residues require deamidation into glutamic acid residues at the anchor sites of the epitope for increased affinity to the HLA receptor. Sollid et al. (11) and Sollid et al. (35) have published a comprehensive list of gluten epitopes. Individual patients develop a set of $\mathrm{T}$ cells, each of which recognizes a different epitope $(36,37)$. Some epitopes are recognized by $\mathrm{T}$ cells in most patients (12). Considering the large number of well-documented and clinically relevant epitopes with DQ2.5 restriction, it seems justified to focus gene-editing/silencing activities on these epitopes.

Both gliadin and glutenins contain immunogenic epitopes within their protein sequences that cause $\operatorname{CD}(34,38)$, but the $\alpha-$, $\gamma$ - and $\omega$-gliadins contain the major and clinically most relevant epitopes $(11,12,39-42)$. These are also called immunodominant epitopes, as most CD patients expressing HLA-DQ2.5 respond to the epitopes DQ2.5-glia- $\alpha 1$ a, DQ2.5-glia- $\alpha 2, \mathrm{DQ} 2.5$-glia- $\omega 1$, and DQ2.5-glia- $\omega 2$, whereas most patients expressing HLADQ8 respond to DQ8-glia- $\alpha 1$ (16). There are few natural $\alpha$ gliadin variants, notably on chromosome $6 \mathrm{~B}$, that are free of immunogenic epitopes $(43,44)$. So far, no food processing or classical breeding strategies have been developed that produce wheat-based food products that approach safety for CD patients (45-47), although there is a clear need to do so $(48,49)$.

Using chemical treatments such as ethyl-methane sulfonate (EMS) or ionizing irradiation, random mutations can 
be generated in the plant genome. These may result in removal of gliadin loci, as has been shown for bread wheat $(23,50)$. Wheat deletion lines produced with irradiation, e.g., those lacking the 6D alpha-gliadin locus with many CD epitopes (50) may be used in a breeding program, but only together with other approaches, as combining multiple chromosomal deletions is often lethal. EMS mutation breeding generates a large number of random mutations (51), it is resource-intensive, requiring extensive breeding to combine deletions in multiple gluten loci, from many plants, into one single, coeliac-safe and well-performing wheat plant (46).

Two modern biotechnology approaches represent promising tools toward producing wheat that is safe for CD patients: RNA interference (RNAi) and CRISPR/Cas9 gene editing (Figure 1). Using RNAi, Gil Humanes et al. (52) targeted $\gamma$-gliadins, while Becker et al. (53) aimed to silence $\alpha$ gliadin genes. Gil-Humanes et al. (25) used RNAi to downregulate all three gliadin gene types resulting in an up to $92 \%$ reduction in the gliadin response, as estimated using the R5 monoclonal antibody (mAb) assay, and a 10-100fold reduction of DQ2 and DQ8 epitopes in T-cell tests. More recently, Altenbach et al. (54) used RNAi to silence $\omega$-gliadins. However, implementation of these methods faces several hurdles. RNAi targets gluten genes indirectly (through their RNA transcripts) and this approach requires stable genetic modification (GM) and transgene expression. Governmental regulations for GM food products require expensive and time-consuming food-safety assessments to be met before product marketing.
The recently developed CRISPR/Cas9 gene editing system has the potential to simultaneously and precisely modify multiple gliadin-encoded epitopes, and/or delete some of the genes, while potentially maintaining the food-technological quality of the gliadin proteins. Application of CRISPR/Cas9 has been successful for targeted mutagenesis of single copy genes across all three homoeologous loci in hexaploid wheat (55). However, mutating target-specific sequences in large gene families in a polyploid species, such as gluten-encoding genes in wheat, has only recently been reported (21-23).

In CRISPR/Cas9 gene editing, a single guide RNA (sgRNA) directs the Cas9 endonuclease to the target DNA sites where it creates a double-strand break. During repair, the innate DNA repair mechanism of the plant can generate mistakes, usually resulting in small deletions of one or a few nucleotides. In the case of the tandemly repeated gliadin genes in wheat, simultaneous double-strand breaks may occur in consecutive genes, which can result in deletion of large DNA fragments carrying one or more gliadin genes (23). Large deletions between multiple target sites have also been obtained, for example in rice (56).

\section{ANALYTICAL METHODS TO CHARACTERIZE CRISPR/CAS9-INDUCED MUTANTS}

The random occurrence of deletions at the target sites, and the large number of targets in the gliadin gene families, means that gene editing will initially produce plants with a mosaic of edited, deleted and unaffected genes. This requires efficient methods to

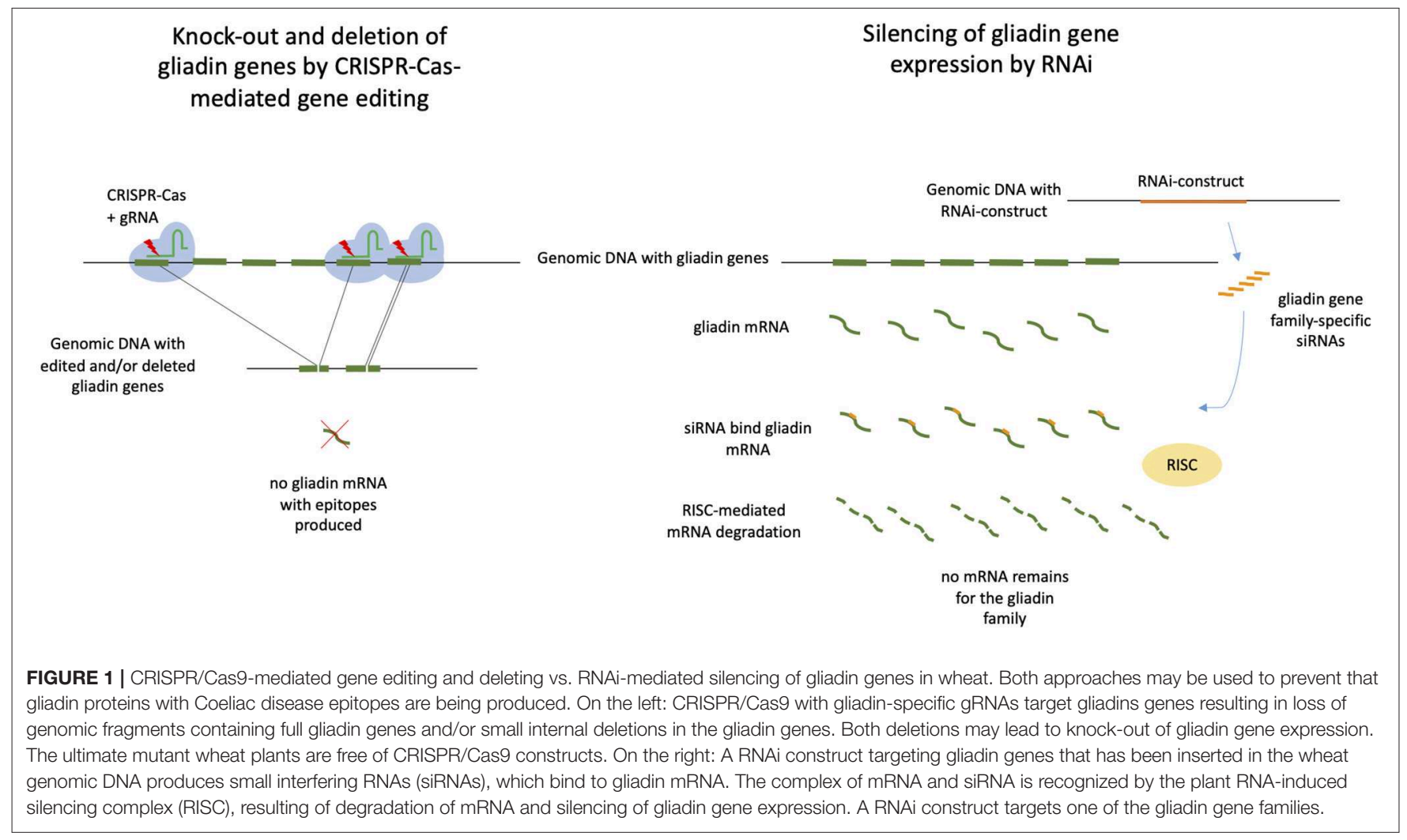


detect the plants with edits, in order to be able to rigorously reduce the number of plants in a program through qualitydirected selection steps. Screening may occur at the DNA level (the number of genes present and their sequences after editing), at the protein level or for baking quality and immunity. The same methods can also be used to characterize RNAi lines, with the exception of screening at the DNA level, as RNAi interferes with the mRNAs after transcription, while the gluten genes themselves remain intact. These methods may be combined into a screening pipeline.

In Table 1, we summarized the screening methods that have been used in the RNAi and CRISPR/Cas9 studies on gluten in wheat published to date. We describe these methods below.

\section{Screening for Edits in Gliadin Genes at the DNA Level}

The hexaploid bread wheat genome is composed of three diploid sub-genomes $(2 \mathrm{n}=6 \mathrm{x}=\mathrm{AABBDD})$, is $\sim 17 \mathrm{~Gb}$ in size, and contains a large number of repeat sequences (59, $60)$. Consequently, sequencing the whole genome of edited lines is not currently feasible and a complexity reduction step is necessary. RNA-seq would reduce complexity, but will not reveal all gluten genes, as not all genes are expressed and gene expression is developmentally and/or environmentally regulated (34). In addition, the immature T1 seeds in which the genes are being analyzed are not available for destructive sampling. Therefore, leaf DNA samples of T0, T1, or later generations are usually sampled. Amplicon sequencing of the target region, or a complexity reduction step on the genomic DNA described below, may then be applied.

\section{Amplicon Sequencing}

In the study by Sánchez-León et al. (21), 47 T1 lines were selected and the CRISPR/Cas9-induced mutation was confirmed by amplifying the target regions using polymerase chain reaction (PCR), followed by Illumina MiSeq sequencing of the amplicons using $2 \times 280$ bp paired-end reads.

\section{GlutEnSeq Enrichment}

A gene enrichment exome-capture methodology was developed by Jouanin et al. (23) to pull down all gluten genes from the wheat genome, thereby reducing DNA complexity before sequencing (61). Termed GlutEnSeq, this approach uses probes that represent all known sequence variations present in thousands of available prolamin gene sequences from numerous Triticum species and varieties (22). The in-solution enrichment system was validated with cv. Chinese Spring deletion lines [(62); a panel of lines, containing deletions spanning defined regions of single chromosomes] and $\gamma$-irradiated lines of cultivar Paragon (Wheat Genetic Improvement Network, UK). Pulled-down gluten genes were sequenced using Illumina MiSeq $2 \times 250$ bp paired-end reads and analyzed against the Chinese Spring RefSeq v1.0 reference genome (63). Analysis of the sequence revealed that gluten gene sequences were generally enriched around 10,000fold. The coverage profile of the $\mathrm{cv}$. Fielder CRISPR/Cas9 gliadin mutant lines revealed examples of a homozygous deletion of the $\gamma$-gliadin Gli-1 locus on chromosome $1 \mathrm{~B}$ and a heterozygous deletion of the $\alpha$-gliadin Gli-2 locus on chromosome $6 \mathrm{~A}$ (23). Further bioinformatic analyses of the sequence reads is still required to determine how effective GlutEnSeq is at detecting small insertion/deletions (indels) at the CRISPR/Cas9 target site in gliadin genes and thus the efficacy in a large screening program.

\section{Droplet Digital PCR (ddPCR)}

An alternative approach is to analyze the number of genes that remain, before proceeding to a sequencing step. ddPCR is a PCRbased assay in which prior to PCR amplification, DNA fragments are partitioned into typically 20,000 water-in-oil droplets. This enables multiple, simultaneous end-point amplification reactions from a single sample with high quantitative precision and reliability. It is a reliable method for high-throughput gene copy number quantification (64), which is relevant for multiple sgRNA CRISPR/Cas9 editing where targeting $\alpha$-gliadins and/or $\gamma$-gliadins $(23,24)$, as this results in plants with different copy number variations (CNV) of the target genes. The accuracy and reliability of ddPCR has been determined for transgene copy number analysis in crops, including wheat (65). Jouanin et al. (24) optimized the method for CRISPR/Cas9-induced mutations in gliadin genes in wheat, and developed duplex ddPCR assays where one part of the duplex assay was directed to a single copy reference gene on each of the six homoeologous wheat chromatids, and the other assay to the target regions in the gliadin genes. The method was validated using selected Chinese Spring deletion lines, Chinese Spring nullisomic/tetrasomic lines [(66); in which one entire chromosome pair is deleted, balanced by an extra pair of the remaining homoeologous chromosomes], Paragon $\gamma$-irradiated lines (which had displayed changes in AcidPAGE gluten protein patterns) and synthetic hexaploid wheat accessions (alongside their component parent species T. durum and Aegilops tauschii) (24).

\section{Screening for Edits in Gliadin Genes at the Protein Level}

Acid-PAGE is a well-known, reliable, non-denaturing gel electrophoresis technique used to differentiate and identify wheat varieties based on their gliadin protein profile. Separation is based on protein molecular weight and charge (67). In RNAi lines, Acid-PAGE clearly showed the down-regulation of groups of protein bands related to gliadin gene families. In geneedited lines it revealed band position changes, as well as band absences, when compared to the wild type (WT) (22). AcidPAGE or SDS-PAGE has been used in all RNAi and CRISPR/Cas9 studies of gliadin genes published to date (Table 1). However, one-dimensional PAGE does not give full information on gluten proteins, since the protein spots overlap, as is visible in 2D-electrophoresis (68-73). Changes in the Acid-PAGE or SDS-PAGE one-dimensional gel electrophoresis profiles should therefore be confirmed by proteomic techniques. Several targeted approaches for quantitative analysis of gliadin and glutenin proteins have been described (74-77).

To characterize the changes in expressed proteins in geneedited wheat lines, various proteomics methods have been employed. The choice of method strongly depends on the 
TABLE 1 | Methods used for screening wheat lines produced using RNA interference or gene editing using CRISPR/Cas9.

\begin{tabular}{|c|c|c|c|c|c|c|c|c|c|}
\hline Technology type & Aim & Applied by & & & & & & & \\
\hline & & (52) & (25) & (53) & (57) & (21) & (22) & (54) & (58) \\
\hline RNAi: & & * & * & * & * & & & * & * \\
\hline \multirow[t]{3}{*}{ CRISPR/Cas9: } & & & & & & * & * & & \\
\hline & Target & $\begin{array}{l}\text { A high-transcript- } \\
\text { level } 169 \text { bp } \\
\text { sequence } \\
\text { targeting most } \\
\gamma \text {-gliadins; testing } \\
\text { RNAi technology }\end{array}$ & $\begin{array}{l}\text { Three plasmid } \\
\text { sequences (all with } \\
361 \text { bp chimeric } \\
\text { conserved } \\
\text { fragments) and } \\
\text { their combinations } \\
\text { to targeting all } \alpha-\text {, } \\
\gamma-\text {, and } \omega \text {-gliadins }\end{array}$ & $\begin{array}{l}\text { A } 313 \mathrm{bp} \\
\text { conserved } \\
\alpha \text {-gliadin fragment } \\
\text { targeting all } \\
\alpha \text {-gliadins }\end{array}$ & $\begin{array}{l}\text { Seven plasmid } \\
\text { sequence } \\
\text { combinations } \\
\text { targeting all } \alpha^{-}, \gamma^{-} \text {, } \\
\text { and } \omega \text {-gliadins and } \\
\text { LMW glutenin }\end{array}$ & $\begin{array}{l}\text { Two sgRNAs } \\
\text { targeting } \\
\text { immuno-dominant } \\
\text { 33-mer } \alpha \text {-gliadin }\end{array}$ & $\begin{array}{l}\text { Six sgRNAs } \\
\text { targeting } \alpha \text { - and } \\
\gamma \text {-gliadin signal } \\
\text { peptide and/or } \\
\text { two epitope } \\
\text { regions }\end{array}$ & $\begin{array}{l}\text { A } 141 \mathrm{bp} \omega \text {-gliadin } \\
\text { fragment targeting } \\
\omega-1,2 \text { gliadin }\end{array}$ & $\begin{array}{l}\text { A } 217 \text { bp fragment } \\
\text { with three targets } \\
\text { from D-genome } \\
\alpha \text {-gliadin genes, } \\
\text { targeting } \\
\alpha \text {-gliadins }\end{array}$ \\
\hline & Transformation & $\begin{array}{l}\text { Particle } \\
\text { bombardment of } \\
\text { scutellum tissue of } \\
\text { two bread wheat } \\
\text { lines; D-Hordein } \\
\text { promoter for } \\
\text { hpRNAs } \\
\text { expression; bar for } \\
\text { PPT selection }\end{array}$ & $\begin{array}{l}\text { Gold particle } \\
\text { bombardment of } \\
\text { immature } \\
\text { scutellum tissue of } \\
\text { two bread wheat } \\
\text { lines; endosperm- } \\
\text { specific promoter; } \\
\text { bar for } \\
\text { PPT-selection }\end{array}$ & $\begin{array}{l}\text { Particle } \\
\text { bombardment of } \\
\text { immature embryos } \\
\text { from a single } \\
\text { cultivar; CaMV } \\
35 \mathrm{~S} \text { promoter; } \\
\text { nptll gene for } \\
\text { kanamycin } \\
\text { resistance }\end{array}$ & $\begin{array}{l}\text { Gold particle } \\
\text { bombardment of } \\
\text { immature } \\
\text { scutellum tissue of } \\
\text { one bread wheat } \\
\text { cultivar; D-Hordein } \\
\text { promoter for } \\
\text { hpRNAs } \\
\text { expression; bar for } \\
\text { PPT-selection }\end{array}$ & $\begin{array}{l}\text { Gold particle } \\
\text { transformation of } \\
\text { scutellum tissue of } \\
2 \text { bread wheat } \\
\text { lines and } 1 \text { durum } \\
\text { wheat cultivar; } \\
\text { Ubiquitin } 1 \\
\text { promoter from } \\
\text { maize; bar for } \\
\text { PPT-selection }\end{array}$ & $\begin{array}{l}\text { Agrobacterium } \\
\text { transformation of } \\
\text { one bread wheat } \\
\text { cultivar; ACTIN } \\
\text { promoter; nptll for } \\
\text { G418-selection }\end{array}$ & $\begin{array}{l}\text { Gold particle } \\
\text { bombardment of } \\
\text { young } \\
\text { embryo-derived } \\
\text { callus from a } \\
\text { single bread wheat } \\
\text { cultivar; HMW-GS } \\
\text { Dy10 promoter; } \\
\text { bar for } \\
\text { PPT-selection }\end{array}$ & $\begin{array}{l}\text { Gold particle } \\
\text { bombardment of } \\
\text { young } \\
\text { embryo-derived } \\
\text { callus from Butte } \\
86 ; \text { maize Ubi1 } \\
\text { promoter; bar for } \\
\text { PPT-selection }\end{array}$ \\
\hline \multicolumn{10}{|l|}{ DNA } \\
\hline PCR & $\begin{array}{l}\text { Confirmation of } \\
\text { presence of transgene } \\
\text { in TO plants }\end{array}$ & + & + & $\begin{array}{l}+ \text { (RT-PCR for } \\
\text { RNAi construct } \\
\text { expression testing) }\end{array}$ & + & + & $\begin{array}{l}\text { + (presence of } \\
\text { Cas9 and all } \\
\text { sgRNAs; TR-PCR } \\
\text { for expression of } \\
\text { Cas9) }\end{array}$ & + & + \\
\hline $\begin{array}{l}\text { Illumina HTP DNA } \\
\text { sequencing }\end{array}$ & $\begin{array}{l}\text { Indel characterization } \\
\text { and quantification }\end{array}$ & NA & NA & NA & NA & + & $\begin{array}{l}+ \text { (applied after } \\
\text { gene-enrichment } \\
\text { in GlutEnSeq } \\
\text { (below) }\end{array}$ & NA & NA \\
\hline $\begin{array}{l}\text { Sanger } \\
\text { sequencing }\end{array}$ & Off-target mutation & NA & NA & NA & NA & $\begin{array}{l}+ \text { (but not } \\
\text { detected) }\end{array}$ & - & NA & NA \\
\hline ddPCR & $\begin{array}{l}\text { HTP gene copy } \\
\text { number (variation) } \\
\text { assessment }\end{array}$ & NA & NA & NA & NA & - & $\begin{array}{l}+ \text { (duplex ddPCR } \\
\text { includes reference } \\
\text { comparison) }\end{array}$ & NA & NA \\
\hline GlutEnSeq & $\begin{array}{l}\text { Gene enrichment; } \\
\text { Identification of large- } \\
\text { and medium-sized } \\
\text { mutations/deletions }\end{array}$ & NA & NA & NA & NA & - & + & NA & NA \\
\hline
\end{tabular}


TABLE 1 | Continued

\begin{tabular}{|c|c|c|c|c|c|c|c|c|c|}
\hline Technology type & Aim & Applied by & & & & & & & \\
\hline \multicolumn{10}{|l|}{ PROTEIN } \\
\hline $\begin{array}{l}\text { Acid-PAGE; } \\
\text { SDS-PAGE }\end{array}$ & Gluten profile analysis & + (Acid-PAGE) & + (Acid-PAGE) & + (SDS-PAGE) & $\begin{array}{l}+ \text { (Acid-PAGE of } \\
\text { T1 seeds for } \\
\text { homozygosity } \\
\text { testing; } \\
\text { Acid-PAGE and } \\
\text { SDS-PAGE of T3) }\end{array}$ & + & + (Acid-PAGE) & + (SDS-PAGE) & + (SDS-PAGE) \\
\hline $\begin{array}{l}\text { 2-DE (2D gel- } \\
\text { electrophoresis) }\end{array}$ & $\begin{array}{l}\text { Intensity measurement } \\
\text { of specific gluten } \\
\text { proteins (in T1 } \\
\text { compared with original } \\
\text { plant) }\end{array}$ & - & - & + & - & - & - & + & + \\
\hline MALDI-TOF & $\begin{array}{l}\text { Confirmation of PAGE } \\
\text { gluten profiles }\end{array}$ & $\begin{array}{l}+ \text { (MALDI-TOF } \\
\text { MS) }\end{array}$ & - & $\begin{array}{l}+ \text { (MALDI-TOF MS } \\
\text { for analysis of } \\
\text { individual spots } \\
\text { from 2-DE) }\end{array}$ & - & + & - & - & - \\
\hline HPLC & $\begin{array}{l}\text { Quantification and } \\
\text { characterization of } \\
\text { individual gliadin and } \\
\text { glutenin protein groups }\end{array}$ & - & $+(\mathrm{RP}-\mathrm{HPLC})$ & $+(\mathrm{RP}-\mathrm{HPLC})$ & $+(\mathrm{RP}-\mathrm{HPLC})$ & $+($ RP-HPLC) & - & - & - \\
\hline nanoLC-MSMS & $\begin{array}{l}\text { Identification of peptide } \\
\text { fragment spectra to be } \\
\text { matched to protein } \\
\text { sequences in } \\
\text { database, and } \\
\text { comparison to control }\end{array}$ & - & - & - & $+(\mathrm{LC}-\mathrm{MS} / \mathrm{MS})$ & - & $\begin{array}{l}+ \text { (measuring } \\
\text { protein reduction } \\
\text { and compensatory } \\
\text { effects) }\end{array}$ & $\begin{array}{l}+ \text { (MS/MS of } \\
\text { isolated 2-DE } \\
\text { spots from control } \\
\text { plant (to confirm } \\
\text { absence of target } \\
\text { protein in } \\
\text { transformed lines) }\end{array}$ & $\begin{array}{l}+ \text { (MS/MS of } \\
\text { isolated 2-DE } \\
\text { spots from control } \\
\text { plant (to confirm } \\
\text { absence of target } \\
\text { protein in } \\
\text { transformed lines) }\end{array}$ \\
\hline \multicolumn{10}{|l|}{ BREAD QUALITY } \\
\hline $\begin{array}{l}\text { SDS } \\
\text { sedimentation }\end{array}$ & $\begin{array}{l}\text { Measuring gluten } \\
\text { strength for prediction } \\
\text { of processing and } \\
\text { end-product qualities }\end{array}$ & - & + & - & + & + & - & + & + \\
\hline Mixing properties & $\begin{array}{l}\text { Assessment of dough } \\
\text { resistance, } \\
\text { development and } \\
\text { stability }\end{array}$ & - & - & - & - & - & - & + (Mixograph) & + (Mixograph) \\
\hline Rheology testing & $\begin{array}{l}\text { Maximum resistance of } \\
\text { dough to extension } \\
\text { (RE) and extensibility } \\
\text { (EX) }\end{array}$ & - & - & + & - & - & - & - & - \\
\hline
\end{tabular}


TABLE 1 | Continued

Technology type Aim

Applied by

IMMUNE RESPONSE

Monoclonal

Total gluten content in $\quad+$ (R5 for total
food; 33-mer is target

peptide for $\mathrm{G} 12$

+ (R5 for total

gliadin content)

- $\quad$ G12 (total gluten

+ R5 and $\mathrm{G} 12$

peptide for G12

content)

gluten content

and impact on

33-mer)

\begin{tabular}{|c|c|c|c|c|c|c|c|c|c|}
\hline $\begin{array}{l}\text { Serum reactivity of } \\
C D \text { patients }\end{array}$ & $\begin{array}{l}\text { Immunogenic potential } \\
\text { of transgenic lines }\end{array}$ & - & - & - & - & - & - & $\begin{array}{l}+(\lg G \text { and } \lg A \\
\text { antibody reactivity) }\end{array}$ & $\begin{array}{l}+(\lg G \text { and } \lg A \\
\text { antibody reactivity) }\end{array}$ \\
\hline $\begin{array}{l}\text { T cell proliferation } \\
\text { response }\end{array}$ & $\begin{array}{l}\text { Testing epitope-specific } \\
\text { reactivity }\end{array}$ & - & $\begin{array}{l}+(\mathrm{TG} 2 \text {-treated } \\
\text { protease-digested } \\
\text { total gluten } \\
\text { extract) }\end{array}$ & - & - & - & - & - & - \\
\hline Food challenge & $\begin{array}{l}\text { Coeliac food safety } \\
\text { assessment }\end{array}$ & - & - & - & - & - & - & - & - \\
\hline \multicolumn{10}{|c|}{ OTHER ASPECTS RELATED TO MUTANT/TRANSFORMED PLANT PERFORMANCE } \\
\hline $\begin{array}{l}\text { Mutation/transgene } \\
\text { stability in T } \\
\text { generations }\end{array}$ & & + (measured in T3) & $\begin{array}{l}+ \text { (aiming at } \\
\text { homozygosity) }\end{array}$ & $\begin{array}{l}+ \text { (stable } \\
\text { integration and } \\
\text { expression in T2) }\end{array}$ & + & + & - & - & - \\
\hline $\begin{array}{l}\text { Absence of } \\
\text { transgenes in } T \\
\text { generations }\end{array}$ & & NA & NA & $\begin{array}{l}\text { NA (3-11 } \\
\text { transgene copy } \\
\text { numbers in } \\
\text { transgenic plant } \\
\text { lines) }\end{array}$ & NA & + & - & NA & NA \\
\hline $\begin{array}{l}\text { Changes in } \\
\text { expression of } \\
\text { other gene families }\end{array}$ & & - & - & $\begin{array}{l}+ \text { (RP-HPLC } \\
\text { analysis of gluten } \\
\text { protein profile: no } \\
\text { changes in } \gamma \text { - and } \\
\omega \text {-gliadin profiles) }\end{array}$ & - & $\begin{array}{l}+ \text { (analysis of } \gamma^{-} \\
\text {and } \omega \text {-gliadin, } \\
\text { LMW and whole } \\
\text { bread wheat } \\
\text { genome by Sanger } \\
\text { sequencing) }\end{array}$ & - & - & $\begin{array}{l}\text { + (silencing of } \\
\text { some HMW } \\
\text { glutenins) }\end{array}$ \\
\hline $\begin{array}{l}\text { Chromosome } \\
\text { number }\end{array}$ & & - & - & - & - & + & - & - & - \\
\hline $\begin{array}{l}\text { Performance } \\
\text { (growth; fertility; } \\
\text { seed } \\
\text { quality/quantity) }\end{array}$ & & $\begin{array}{l}\text { + (full fertility; } \\
\text { normal grain } \\
\text { morphology and } \\
\text { weight) }\end{array}$ & + & $\begin{array}{l}+ \text { (full fertility; } \\
\text { normal seed set } \\
\text { and grain } \\
\text { morphology; }\end{array}$ & $\begin{array}{l}\text { + (fertility; days to } \\
\text { anthesis normal; } \\
\text { kernel weight } \\
\text { differences) }\end{array}$ & + & - & $\begin{array}{l}\text { + (fertility; normal } \\
\text { kernel weight) }\end{array}$ & $\begin{array}{l}+ \text { (fertility; normal } \\
\text { kernel weight) }\end{array}$ \\
\hline
\end{tabular}

NA, not applicable. 
available equipment. With regard to the approach, non-targeted proteomics analysis of the prolamin fraction would be most appropriate for situations with novel changes in the gluten proteome. However, proteomics is complicated for this set of gene families, and a complete description of the peptidome generated by wheat digestion is complex (78). The identification of proteins in a non-targeted proteomics analysis depends to a large extend on the availability of the protein sequence information (79). However, in particular, gene editing may generate novel peptides that are not present in any library and can only be predicted by sequencing all gluten genes in each geneedited line. Most studies use a targeted approach, focusing on a small set of peptides as reference for a class of gluten proteins $(76,77,80)$. The extraction procedure used is also relevant, as it has impact on proteins and peptides recovered $(81,82)$.

\section{Matrix-Assisted Laser Desorption/Ionization With Time-of-Flight Mass Spectrometer (MALDI-TOF)}

Gil Humanes et al. (52) used MALDI-TOF to identify and quantify peptides derived from glutenins and gliadins, as a method to quantify the amount of those proteins present in grains of their RNAi lines.

\section{High-performance liquid chromatography (HPLC)}

Sánchez-León et al. (21) used reversed-phase high-performance liquid chromatography (RP-HPLC) to quantify glutenins and gliadins in half-seeds of CRISPR/Cas9 lines.

\section{HPLC and Mass Spectrometry (MS)}

García-Molina et al. (48) studied the impact of silencing of RNAi lines on both target and on non-target proteins. They performed separate analyses on four kernel protein fractions, including gliadins and glutenin fractions, by combining a 2D electrophoresis gel analysis with RP-HPLC and nanoelectrospray ionization mass spectrometry (nESI-MS/MS) of individual protein spots excised from the gels. Liquid chromatography-tandem mass spectrometry (LC/MS/MS) data were used as queries in searches against UniProt and TrEMBL databases.

For a detailed review on the use of proteomics methodology as a tool for screening for immunogenic peptides in cereals we refer to Alves et al. (79).

\section{Bread Quality of Gliadin Gene Edited Wheat Lines}

Wheat with less gluten, or with gluten that does not contain $\mathrm{CD}$ epitopes, needs to retain baking quality to be acceptable to producers and consumers as new gluten-free products (46). SDS sedimentation, mixing properties and rheology testing can all be performed on a small scale, but require grain of fixed-edit lines to be multiplied. For example, $10 \mathrm{~g}$ of seed are needed for a dough extensibility test using a Micro-Farinograph $(83,84)$. That means that one or two extra rounds of seed multiplication must be carried out before dough properties can be studied. Most studies in Table 1 have determined SDS sedimentation volumes, but only $(53,54,58)$ tested rheology, as well as $(85)$.

\section{Immune Response of Gliadin Gene Edited Wheat Lines}

Kits based on the monoclonal antibodies (mAbs) R5 or G12 are routinely used to measure the amount of gluten in foodstuffs, as they recognize short peptides that are present in many gliadins. They have used to measure the decrease in gluten content in RNAi lines (Table 1). However, they are not accurate when using in CRISPR/Cas9 lines if the target sequence edited are the CD epitopes. This is because as the $\mathrm{mAb}$ recognition site is much shorter than the nine amino acid epitopes recognized by the CD-immunologically relevant human $\mathrm{T}$ cells, a single amino acid replacement in the epitope induced by gene editing maybe sufficient to abolish binding $(15,38)$, but may go unnoticed when screening with mAbs.

Human $\mathrm{T}$ cells that recognize gluten epitopes have been cultured and they can be used for assays, but the reaction is very specific, and qualitative rather than quantitative $(38,86)$. The $\mathrm{T}$ cells will only proliferate when the 9-amino acid peptide that they recognize is present (usually after deamidation). Each patient has many $\mathrm{T}$ cell clones that recognize $\mathrm{CD}$ epitopes, but across patients there are $\mathrm{T}$ cells that recognize the same, "major" epitopes (12), and gliadins with these epitopes are the main target of gene editing. The major epitopes are listed in Sollid et al. (11) and Sollid et al. (35). T cell tests have been performed in a few of the studies in Table 1.

\section{Clinical Trials}

Clinical trials with food challenges are meaningful once the other tests indicate that the level of major CD epitopes is very low. Serum reactivity and $\mathrm{T}$ cell proliferation responses have been measured in some studies. Larger amounts of wheat flour are required in order to bake bread for human food challenges. GilHumanes et al. $(87,88)$ produced and tested bread using wheat flour from an RNAi line with very low content of gliadins and acceptable baking and sensory properties. The bread has been tested for safety in rats (89) and subsequently it has been used in a food challenge with people with NCWS (90). Challenged and control people both did not show gluten immunogenic peptides in their stools and responded similarly in a Gastrointestinal Symptom Rating Scale (GSRS) questionnaire. Consumption of low-gliadin bread increased butyrate-producing bacteria and favored a microbial profile that may improve gut quality (90).

\section{COMBINING METHODS INTO PIPELINES TO EFFICIENTLY SCREEN CRISPR/CAS9 WHEAT MUTANT LINES}

There are many tens of gluten CRISPR/Cas9 gene targets in the wheat genome. Each regenerated plant (T0 generation) from a single gene editing experiment may be a mosaic of deleted, modified and unchanged genes. Initially the edits may be present in heterozygous form. Analysis of T1 seeds revealed that of about 50 different highly presented $\alpha$-gliadin sequences in bread wheat and durum wheat, $25-78 \%$ were mutated by CRISPR/Cas9 as determined by Illumina sequencing (21), while Acid-PAGE analysis of CRISPR/Cas9 derived germplasm has found up to $30 \%$ 
of the proteins had changed (22). In the next generation of selfpollinated transformed plants, segregation of heterozygous edits will occur. The numbers of seeds to be analyzed will increase considerably; from each T1 wheat seed a plant with 5 ears, each containing 50 seeds, can develop. Efficient analysis of high numbers of progeny seeds becomes relevant: hundreds of seeds may be required to be screened from tens of T0 transformants, and a fast method for pre-screening is therefore required. The T1 generation in the study of Sánchez-León et al. (21) consisted of 6-12 mature T1 grains from each of the $21 \mathrm{~T} 0$ plants obtained, so in the order of 200 plants. Jouanin et al. (22) tested 1,149 T1 seeds obtained from 117 regenerated T0 plants.

For an analysis pipeline to be applicable for high-throughput screening, ideally it should reduce the number of lines to be tested at the earliest possible stage, i.e., in the first and second step. The pipeline should employ cheap or fast screening methods to detect the presence of differences in DNA of gluten protein, without the need for precise characterization, as that may be done subsequently on a much-reduced number of lines. We summarize this approach schematically in Figure 2, and below we describe the steps used in two examples of screening pipelines that have been applied in recent CRISPR/Cas studies. A general description of the relative advantages and disadvantages of each of the methods in terms of accuracy, time requirement and cost effectiveness cannot be given, as this depends very much on the equipment and experience present in the laboratory. For instance, while some labs may have used acid PAGE routinely, others may not have done so and may therefore prefer SDS-PAGE. Not all labs have a ddPCR machine. Proteomics methods strongly depend on the availability of highly specialized equipment.

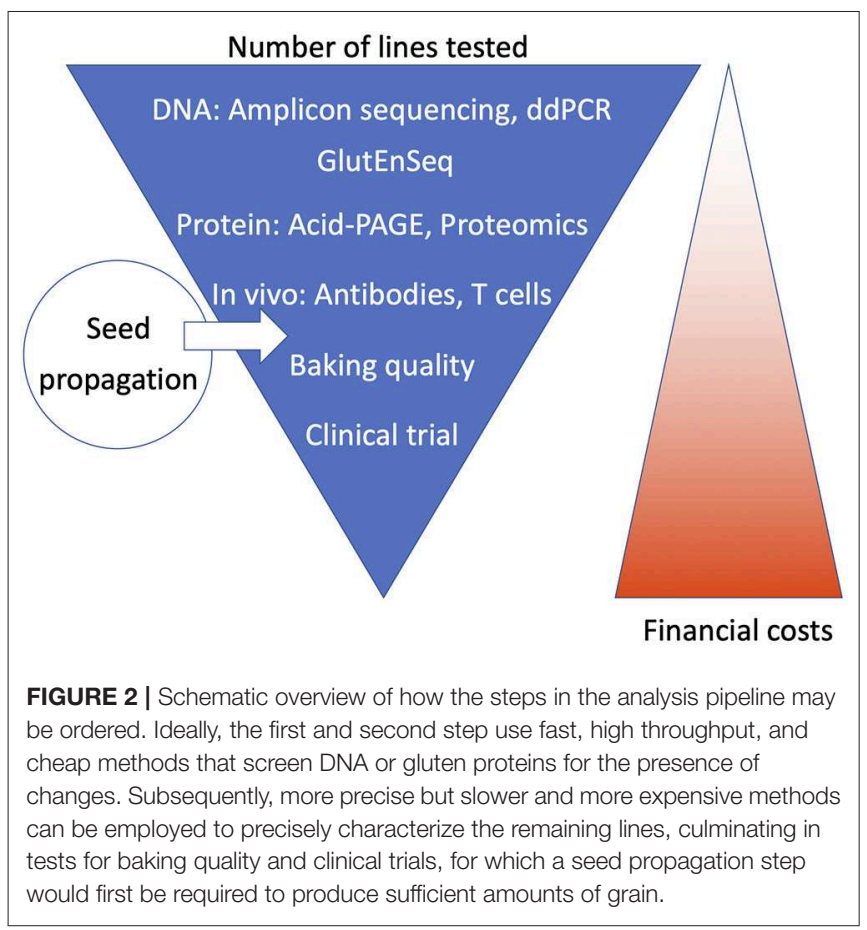

\section{The $\alpha$-Gliadin 33-Mer Target Approach}

Sánchez-León et al. (21) focused on a series of analytical techniques to make an in-depth evaluation of gene-edited events over three generations (T0 to T3). This was to understand the effects and efficacy of CRISPR/Cas9 toward a coeliac-safe end product. Their pipeline was therefore not primarily intended to be a sequential-selection pipeline designed to reduce the numbers of mutant lines and retain only the "most promising" mutants. The pipeline consisted of four steps:

(1) Illumina DNA sequencing to characterize the DNA extracted from leaves harvested from T1 transgenic plants and the corresponding wild-types to measure the frequency and types of indels. Deletions up to $126 \mathrm{bp}$ and insertions of up to $158 \mathrm{bp}$ were found. Remarkably, most of the deletions in the target region ( $\alpha$-gliadins possessing the immuno-dominant epitope-containing 33-mer peptide fragment) were multiples of $3 \mathrm{bp}$; deletions of $-3,-9,-36$, and -78 bp were observed at high frequencies in the three selected $\mathrm{T} 1$ mutant lines from the reported transformed bread wheat cultivar. High frequencies of frameshift-inducing -1 and +1 bp (typical for CRISPR/Cas9 mutations) were, however, not found.

(2) Subsequently, to assess the impact of the observed mutations on seed gluten protein composition, $\mathrm{T} 1$ seeds of several tens of plants each from five selected T0 plants were assessed qualitatively for protein composition changes using Acid- and SDS-PAGE, and further quantitatively analyzed by MALDI-TOF and confirmed by HPLC. The mutant lines reported showed reduced total gliadin content (specifically the $\alpha$-gliadins), increased glutenin content (especially HMW) due to a compensatory effect and, as a result, a lower gliadin/glutenin ratio.

(3) Confirmation of significantly reduced $\alpha$-gliadin content in mutant lines was followed by investigation of any reduction in immune reactivity, for which $\mathrm{T} 2$ seeds were analyzed with R5 and G12 monoclonal antibodies. An average reduction of over $60 \%$ total gluten was found, with an $85 \%$ reduction in gluten content observed in one line.

(4) Finally, bread-making quality of mutant lines was assessed using the SDS sedimentation test. Using flour produced from bulked T2 and T3 seeds of several mutant lines, SDS sedimentation results predicted reasonably good quality and bread-making performance for the edited lines.

While this pipeline identified and characterized mutations in gliadins, there are a number of other issues that were considered: (a) CRISPR/Cas9 mutagenesis may create off-target mutations. Accordingly, Sánchez-León et al. (21) carried out Sanger sequencing of cloned $\alpha-, \gamma$-, and $\omega$-gliadin genes and of the entire wheat genome (with specific focus on loci containing the presence of potential off-target sites) from mutant lines and were able to conclude that no off-target mutations had occurred. This demonstrated the high specificity of the chosen sgRNAs. (b) Another issue relates to the transmission of the mutations to subsequent generations. Via RP-HPLC and Illumina sequencing, the inheritance of the gliadin and glutenin profile (prolamin phenotype) was confirmed. Interestingly, presence or absence of the Cas9 expression vector in T2 plants did not 
appear to affect mutation frequencies compared to the original T0 plant. (c) PCR and Illumina sequencing were also used to test whether any of the gene-edited low-gluten wheat lines lacked the transgene and insertions at the cleavage site. Three bread wheat and six durum wheat lines were identified as transgenefree and insertion-free. These lines were fully fertile, set seeds and had normal chromosome numbers. (d) The resulting lowgluten, transgene construct-free wheat lines may provide useful source material to introgress the low-gluten/low-immunogenic trait into elite wheat varieties, or to undertake further iterative CRISPR/Cas9-mediated improvement.

\section{$\alpha$ - and $\gamma$-Gliadin Multiple Target Approach}

Jouanin et al. (22) edited $\alpha$ - and $\gamma$-gliadins with multiple gsRNAs in a single construct. Notably, $\alpha$-gliadins are present as tandem repeats on the group 6 chromosomes. Therefore, it is possible that repair of simultaneous double-strand breaks in such regions could lead not only to small deletions but also to "allele drop out." The optimized pipeline for screening of the plants produced would consist of the following steps.

(1) DNA is extracted from young T1 leaves and analyzed using ddPCR for changes in gene copy number. ddPCR can measure whether gliadin genes are deleted compared to the number present in the original Fielder plant (24).

(2) Proteins are extracted from the endosperm of selected "promising" T1 seeds for Acid-PAGE analysis to look for the corresponding changes in protein profiles, i.e., gliadin bands that are missing compared to the original plant (22).

(3) Leaf DNA from the best candidate T1 lines is then used to perform GlutEnSeq (23). The captured gluten genes are sequenced and compared to the corresponding gluten genes pulled down from the original variety. In this way changes in the DNA sequence of gluten genes can be identified.

(4) The most interesting edited wheat lines from the GlutEnSeq analysis are self-pollinated and the resulting T2 or T3 seeds analyzed at the protein level using LC-MSMS.

Once identified, gene-edited lines that are complementary based on the types and numbers of eliminated or inactivated coeliacimmunogenic epitopes they carry, can be crossed to combine the gene-edited gliadins. The progeny should also be screened to select against inheritance of the CRISPR/Cas9 construct. The resulting genetically stable plants can be analyzed and selected following the pipeline above, up to the LC-MSMS step. GlutEnSeq enrichment followed by MiSeq sequencing of lines selected using this pipeline will enable the gsRNAs to be fine-tuned to those remaining genes that need to edited. Subsequent analysis via LC-MSMS should be limited to the most-promising lines only, due to the complexity and labor costs of the analysis. Ultimately, lines with multiple geneedited gliadins would require advanced proteomics analysis (see above), followed by immunological assays (including epitope-specific $\mathrm{mAbs}$ or $\mathrm{T}$ cells) whereby the flour from new epitope-mutant wheat lines would be screened with panels of $\mathrm{T}$ cell clones to test for a CD-hypoimmunogenic reaction. Ultimately confirmation through human intervention studies, involving analysis of biopsies from the small intestine or analysis of IgA anti-TG2 antibody levels in serum, would be needed.

\section{TECHNICAL CONSIDERATIONS FOR CD-HYPOIMMUNOGENIC GLUTEN}

Up to now, the use of RNAi has resulted in the E82 line with strongly reduced levels of gliadins, that has been tested on people with NCWS (90). This line had good dough quality while the gliadin level was strongly reduced.

With CRISPR/Cas9 it is possible to edit all gliadin epitopes by causing local deletions and frameshifts. However, after the first round of edits, modifying the few remaining epitopes in some of the genes would require multiple rounds of additional edits. Specific amino acid substitutions in a gliadin epitope can abolish its immunogenicity (38) whilst having no effect on gene expression and thus on bread dough quality. With new developments in gene editing being published almost monthly, these options may become available soon, meaning that the goal of editing the wheat gluten genes at the epitope level into CDsafe wheat lines may be realized (26). Base editors are very promising. For this, CRISPR systems have been developed with a deactivated Cas9 (dCas9) or a Cas9 single strand nuclease (nickase) fused to a second active enzyme such as cytidine deaminase. The sgRNA directs the dCas9-cytidine deaminase to the target site, to enable deamination of a target cytosine into a uracil, which is subsequently converted to a thymine through DNA replication and repair. This approach has recently proven successful in wheat (91). Adenine deaminase-based DNA base editors have also been developed recently to extend the range of amenable target sites [reviewed in e.g., Eid et al., (92)].

In theory, an alternative to base editing is gene correction or gene replacement $(93,94)$. Techniques for this do not yet have the efficiency required for editing a gene family. It would be promising for template-based targeted replacement of CD-immunogenic genes by safe gene variants from the same accession or variety. For instance, Van Herpen et al. (43) identified some presumably safe $\alpha$-gliadin genes at the Gli-2 locus on chromosome 6B. Duplication of these genes through gene replacement at the loci on $6 \mathrm{~A}$ and $6 \mathrm{D}$ would efficiently remove many immunogenic epitopes. Prime editing (95) would be a suitable technique for this goal. The screening of plants produced by this approach would be relatively straightforward, as the desired changes are defined beforehand. This could offer the safest approach, as the replaced genes would be exact copies of existing genes that are considered safe.

These alternatives make it more feasible to maintain the complete gluten proteome, while removing CD-epitopes. This may be advantageous, because removal of gluten loci may trigger protein compensation due to overexpression of remaining gluten genes (96), which may promote other CD-immunogenic epitopes, and would negatively affect bread dough rheology and other food technological characteristics as well. Compensation effects by increased production of $\omega$-gliadins, which also have 
CD epitopes, have for instance been found in the CRISPR/Cas9 $\alpha$-gliadin edited wheat lines of Sánchez-León et al. (21).

As CRISPR/Cas9-induced deletions and the alternative strategies above present advantages, inconveniences and uncertainties for editing gliadin genes toward wheat with hypoimmunogenic gluten, one strategy would be to combine several of these methods sequentially to generate the safest wheat variety for CD-patients while retaining sufficient baking quality. As an example, in a single wheat plant, the $\alpha$-gliadin gene family (having the least diversity and being the best characterized) could have their immunogenic epitopes replaced by known safe ones using the Cas9/template approach, while the more complex $\gamma$ and $\omega$-gliadin genes families on the group 1 chromosomes could be deleted. As a result, no CD-immunogenic gliadin epitopes would remain but $\mathrm{CD}$-safe $\alpha$-gliadin proteins would still be produced which retained the viscosity characteristics necessary for bread dough quality.

Finally, rather than relying on modified gliadins that are probably safe, the safest approach would be to design gliadins that are absolutely inert by avoiding the spacing of specific amino acids that enable gliadin peptides to fit into the groove of the HLA-DQ2.2-T cell, HLA-DQ2.5-T cell or the HLA-DQ8-T cell complexes, and insert these in lines without native gluten genes. These genes can be designed, as the structural requirements of these complexes have completely been elucidated (13-16, 97-99) and they can be introduced into the DNA replacing toxic gluten genes using newly developed tools such as Prime editing (95).

\section{ISSUES REGARDING THE FUTURE OF GENE EDITING OF WHEAT FOR CD-HYPOIMMUNOGENIC GLUTEN}

\section{Immunology}

In theory, CRISPR/Cas9 editing could result in the generation of peptide sequences that have the potential to become new epitopes. However, newly formed epitopes that are clinically relevant are likely to be similar in amino acid sequence order to existing epitopes and thus could be screened out. In addition, the flour from new, epitope-mutant wheat lines would be screened with panels of $\mathrm{T}$ cell clones to test for a CDhypoimmunogenic reaction. As a final precaution, testing at the pilot product level with volunteer patients would need to be carried out prior to market introduction. With the current improvements and fine-tuning of gene-editing techniques close at hand, it is realistic to face the future positively and to embrace the opportunities offered by gene-editing. Monitoring of possible negative, clinically-relevant effects after large-scale market introduction of gene-edited wheat should however be standard.

\section{Regulation Concerning GM}

RNAi requires foreign DNA (with inverted copies of a piece of the target gene(s)) to be present in plants. Gene editing requires foreign DNA (constructs encoding zinc finger proteins, TALENs, or Cas9 plus guide RNAs in case of CRISPR/Cas9) or proteins to be introduced in plant genomes or plant cells, as a transient step to enable editing of the target genes. Foreign DNA will be segregated out in subsequent generations, so that they are not present in the final gene-edited lines and the end products. In an alternative approach, Cas9 protein plus guide RNAs are introduced into cells, avoiding transformation and subsequent need for segregation to remove the construct. The issue which needs to be addressed is whether to regulate geneedited plants-and derived products-according to a processbased or a product-based approach. A process-based approach would consider that induced mutations would fall under GM regulations, even if foreign DNA or proteins were not present in the final plant. Conversely, a product-based approach would consider the absence of foreign DNA or protein in the final gene-edited plant as similar to traditional breeding, where the presence of similar mutations in plants obtained through spontaneous or mutation breeding e.g., through use of $\gamma$ irradiation or EMS, are exempted from GM regulations. Such mutation breeding approaches follow conventional breeding rules because of a history of "safe use," and have been exempted from EU regulation by putting them on Annex $1 \mathrm{~B}$ of the GMO Directive 2001/18/EC (100).

On July 25th 2018 the European Court of Justice ruled that, according to the text of the Directive 2001/18/EC (100), plants produced with gene editing as a mutation technique are not exempted from GM regulation as long as it has not been "conventionally used" in "a number of applications" and have "a long safety record” $(101,102)$. In contrast, many other countries have chosen not to regulate plants produced with gene editing as GM, provided no foreign DNA is present in the final product. Canada will evaluate them within their existing framework for Plants with Novel Traits. Consequently, gene-edited wheat lines with hypoimmunogenic gluten and derived products can be developed and widely commercialized, but they will not be accepted in the EU without fulfilling costly GM-related tests and labeling [up to 100 million euro per case; (103)]. This decision will have serious consequences within the EU regarding the application of the technique, for companies with regard to the production of CD-safe wheat varieties and derived food products, and for CD-patients with regard to the availability of such safe foods $(104,105)$.

\section{Public Acceptance}

It has been shown that people suffering from food-related disorders are usually positive about the development of healthier products for their disorder. This positive attitude has also been observed in non-patients regarding the personal benefit of health-safe and health-promoting application of GM technologies $(106,107)$. For patient societies, the methods used to produce safe food are not an issue. Their concern relates to proper testing and labeling, so that coeliacs can distinguish gluten-free wheat or wheat with safe gluten from "normal" wheat, which will lead to stricter regulation of food packaging and ingredient information. If there is ultimately success in producing wheat varieties with acceptable levels of gluten through gene editing techniques, it will be of interest to see whether such a valuable trait can contribute to a change of heart and mind of 
the general public toward the application of biotechnology for safe food.

\section{Gluten-Free Food Labeling}

Currently, products labeled as gluten-free have to contain $<20 \mathrm{ppm}$ of gluten (108), which is assessed using R5-ELISA (R-Biopharm, Darmstadt, Germany), the recommended type I method according to the Codex Alimentarius Commission (109) and Bruins Slot et al. (110). However, in the case of analyzing products made of hypoimmunogenic wheat/gluten, measuring the total gluten content of the product is no longer relevant. Rather, it is the total amount of immunogenic peptides that is relevant. Since monoclonal antibodies recognize only a maximum of five or six amino acid sequences within a protein, they are unable to detect complete 9-amino-acid long $\mathrm{T}$ cell epitopes, nor will they be able to distinguish intact epitopes from epitopes with one or two amino acid replacements, even though this may be sufficient to abolish immunogenicity (38). Therefore, proteomics techniques are required for the assessment of gluten status. A first step toward this has been made: a mass spectrometric (LC-MRM/MS) method has been developed to detect quantitatively and simultaneously a set of specific CDepitopes at the femtomolar detection level in wheat seed extracts in a high-throughput manner $(74,78,111)$.

\section{Food Technology}

An intermediate goal is wheat lines with greatly reduced epitope numbers related for some or all gliadin families. These lines may not be sufficiently safe for sensitive CD patients, but they would reduce the induction of the disease in susceptible people (children, as well as adults) since gluten dosage correlates with the induction of the disease (112).

\section{Production Chain Requirements}

When hypoimmunogenic wheat varieties make it to the market, whether made by gene editing, RNAi, alone or in combination with other approaches [such as low prolamin mutations (113)], it will initially require a separate production chain, implying completely separated facilities for hypoimmunogenic wheat on farms, at the processing factory, and all the way to packaging and labeling, to avoid any risks of contamination with other grains containing immunogenic gluten epitopes. If such products are well-accepted and the market grows, consumers may prefer safe wheat over regular wheat, even if they are not coeliac patients themselves, so more products will be made with hypoimmunogenic gluten. At some point they may be considered as the new standard for gluten. In that case, the main production chain in, for example, a region, could become gluten-safe. In the long run, this trend could expand, replacing regular wheat varieties by hypoimmunogenic ones, and abolishing the need for separate production chains-although strict precautions should remain in place to avoid contamination with related species that contain immunogenic gluten epitopes.

\section{CONCLUSIONS}

Gene editing using CRISPR/Cas9 offers the prospect of producing hypoimmunogenic wheat. RNAi has been used to make low-gliadin lines. We have presented a range of methods, which combined, enable the seeds from such programs to be efficiently screened. There is still a long way to go in order to make wheat completely safe for coeliacs, as wheat has 100200,000 ppm gluten and the number of epitopes has to be decreased to the equivalent of $20 \mathrm{ppm}$. This may mean that several approaches must be combined, and almost certainly, that edited genes from different lines must be combined by crossing and selection within a breeding program. Some of the methods are also suitable for screening during such a breeding program and for determining the safety and quality of the grain produced.

\section{AUTHOR CONTRIBUTIONS}

This paper was initiated from the General Discussion on a screening pipeline in the Ph.D. thesis of AJ. LG expanded the text and produced Table 1. JS made Figure 1. LG, MS, and JC made Figure 2. MS did the final editing. All other authors were involved in extensive additions and revisions to produce a review of methods. All have read and approved the final version.

\section{FUNDING}

AJ was supported by the 7th Framework Program Max-CROP project (FP7-PEOPLE-2013-ITN-607-178). The writing of this paper was supported in part by (1) the Healthgrain Forum and by the ICC-Vienna Well-on-Wheat (WoW) project (https://www. um-eatwell.nl/wow/), partly funded by the Dutch Topsector AgriFood project TKI 1601P01, (2) by UK Biotechnology and Biological Sciences Research Council (BBSRC) grant BB/L011700/1 to JC, (3) BBSRC Cross-Institute Strategic Programme Designing Future Wheat BB/P016855/1 (FL) and (4) BBSRC grant BB/R014876/1 (EW).

\section{REFERENCES}

1. Gilissen LJ, van der Meer IM, Smulders MJM. Strategies to reduce or prevent wheat coeliac- immunogenicity and wheat sensitivity through food. In: Koehler P, editor. Proceedings of the 29th Meeting of the Working Group on Prolamin Analysis and Toxicity. Tulln (2015). pp. 41-54. Available online at: www.wgpat.com/proceeding_29th.pdf

2. Gilissen LJ, Van den Broeck HC. Breeding for healthier wheat. Cereal Foods World. (2018) 63:132-6. doi: 10.1094/CFW-63-4-0132

3. Miedaner T, Longin F. Unterschätzte Getreidearten. Einkorn Emmer. Clenze: Dinkel and Co. Agrimedia Verlag (2012).

4. FAOSTAT (2018). Available online at: http://www.fao.org/faostat/en/\# search/wheat

5. Atchison J, Head L, Gates A. Wheat as food, wheat as industrial substance; comparative geographies of transformation and mobility. Geoforum. (2010) 41:236-46. doi: 10.1016/j.geoforum.2009.09.006

6. Ross AB, van der Kamp JW, King R, Le KA, Meiborn H, Seal $\mathrm{CJ}$, et al. Perspective: a definition for whole grain food products - 
recommendations from the Healthgrain Forum. Adv Nutr. (2017) 8:525-31. doi: 10.3945/an.116.014001

7. Zong G, Gao A, Hu FB, Sun Q. Whole grain intake and mortality from all causes, cardiovascular disease, and cancer: a meta-analysis of prospective cohort studies. Circulation. (2016) 133:2370-80. doi: 10.1161/CIRCULATIONAHA.115.021101

8. Gilissen LJWJ, Van der Meer IM, Smulders MJM. Reducing the incidence of allergy and intolerance to cereals. J Cereal Sci. (2014) 59:337-53. doi: $10.1016 /$ j.jcs.2014.01.005

9. Brouns F, van Rooy G, Shewry P, Rustgi S, Jonkers D. Adverse reactions to wheat or wheat components. Comprehen Rev Food Sci Food Saf. (2019) 18:1437-52. doi: 10.1111/1541-4337.12475

10. Sharma N, Bhatia S, Chunduri V, Kaur S, Sharma S, Kapoor P, et al. Pathogenesis of celiac disease and other gluten related disorders in wheat and strategies for mitigating them. Front Nutr. (2020) 7:6. doi: $10.3389 /$ fnut.2020.00006

11. Sollid LM, Qiao SW, Anderson RP, Gianfrani C, Koning F. Nomenclature and listing of celiac disease relevant gluten T-cell epitopes restricted by HLA-DQ molecules. Immunogenetics. (2012) 64:455-60. doi: 10.1007/s00251-012-0599-z

12. Tye-Din JA, Stewart JA, Dromey JA, Beissbarth, T, van Heel DA, Tatham A, et al. Comprehensive, quantitative mapping of $\mathrm{T}$ cell epitopes in gluten in celiac disease. Sci Transl Med. (2010) 2:41ra51. doi: $10.1126 /$ scitranslmed.3001012

13. Petersen J, Montserrat V, Mujico JR, Loh KL, Beringer DX, Van Lummel $\mathrm{M}$, et al. T-cell receptor recognition of HLA-DQ2-gliadin complexes associated with celiac disease. Nat Struct Mol Biol. (2014) 21:480. doi: $10.1038 / \mathrm{nsmb} .2817$

14. Petersen J, Kooy-Winkelaar Y, Loh KL, Tran M, Van Bergen J, Koning F, et al. Diverse T cell receptor gene usage in HLA-DQ8-associated celiac disease converges into a consensus binding solution. Structure. (2016) 24:1643-57. doi: 10.1016/j.str.2016.07.010

15. Sollid LM. The roles of MHC class II genes and post-translational modification in celiac disease. Immunogenetics. (2017) 69:605-16. doi: 10.1007/s00251-017-0985-7

16. Dahal-Koirala S, Ciacchi L, Petersen J, Risnes LF, Neumann RS, Christophersen A, et al. Discriminative T-cell receptor recognition of highly homologous HLA-DQ2-bound gluten epitopes. J Biol Chem. (2019) 294:941-52. doi: 10.1074/jbc.RA118.005736

17. Scherf KAC, Catassi C, Chirdo FG, Ciclitira PJ, Feighery C, Gianfrani C, et al. Recent progress and recommendations on celiac disease from the Working Group on Prolamin Analysis and Toxicity. Front Nutr. (2020) 7:29. doi: $10.3389 /$ fnut. 2020.00029

18. Jabri B, Sollid LM. T cells in celiac disease. J Immunol. (2017) 198:3005-14. doi: 10.4049/jimmunol.1601693

19. Schaart JG, van de Wiel CC, Lotz LA, Smulders MJ. Opportunities for products of new plant breeding techniques. Trends Plant Sci. (2016) 21:43849. doi: 10.1016/j.tplants.2015.11.006

20. Van de Wiel CCM, Schaart JG, Lotz LAP, Smulders MJM. New traits in crops produced by genome editing techniques based on deletions. Plant Biotechnol Rep. (2017) 11:1-8. doi: 10.1007/s11816-017-0425-z

21. Sánchez-León, S, Gil-Humanes, J, Ozuna CV, Giménez MJ, Sousa, C, Voytas DF, et al. Low-gluten, nontransgenic wheat engineered with CRISPR/Cas9. Plant Biotechnol J. (2018) 16:902-10. doi: 10.1111/pbi.12837

22. Jouanin A, Schaart JG, Boyd LA, Cockram J, Leigh FJ, Bates R, et al. Outlook for coeliac disease patients: towards bread wheat with hypoimmunogenic gluten by gene editing of $\alpha$-and $\gamma$-gliadin gene families. BMC Plant Biol. (2019) 19:333. doi: 10.1186/s12870-019-1889-5

23. Jouanin A, Borm T, Boyd LA, Cockram J, Leigh F, Santos BA, et al. Development of the GlutEnSeq capture system for sequencing gluten gene families in hexaploid bread wheat with deletions or mutations induced by $\gamma$-irradiation or CRISPR/Cas9. J Cereal Sci. (2019) 88:157-66. doi: $10.1016 /$ j.jcs.2019.04.008

24. Jouanin A, Tenorio-Berrio R, Schaart JG, Leigh F, Visser RGF, Smulders MJM. Optimization of droplet digital PCR for determining copy number variation of $\alpha$-gliadin genes in mutant and gene-edited polyploid bread wheat. J Cereal Sci. (2020) 92:102903. doi: 10.1016/j.jcs.2019.102903
25. Gil-Humanes J, Pistón F, Tollefsen S, Sollid LM, Barro F. Effective shutdown in the expression of celiac disease-related wheat gliadin T-cell epitopes by RNA interference. Proc Natl Acad Sci USA. (2010) 107:17023-8. doi: $10.1073 /$ pnas. 1007773107

26. García-Molina MD, Giménez MJ, Sánchez-León S, Barro F. Gluten free wheat: are we there? Nutrients. (2019) 11:487. doi: 10.3390/nu110 30487

27. Weegels PL, van de Pijpekamp AM, Graveland A, Hamer RJ, Schofield JD. Depolymerisation and re-polymerisation of wheat glutenin during dough processing. I. Relationships between glutenin macropolymer content and quality parameters. J Cereal Sci. (1996) 23:103-11. doi: $10.1006 /$ jcrs. 1996.0010

28. Shewry PR, D’Ovidio R, Lafiandra D, Jenkins JA, Mills EC, Békés F. Wheat grain proteins. In: Khan $\mathrm{K}$, Shewry PR, editors. Wheat: Chemistry and Technology, 4th Edn. Elsevier Inc. in cooperation with AACC International (2009). p. 223-98. doi: 10.1016/B978-1-891127-55-7.50015-X

29. Shewry PR. What is gluten-why is it special? Front Nutr. (2019) 6:101. doi: $10.3389 /$ fnut.2019.00101

30. Clavijo BJ, Venturini L, Schudoma C, Accinelli GG, Kaithakottil G. An improved assembly and annotation of the allohexaploid wheat genome identifies complete families of agronomic genes and provides genomic evidence for chromosomal translocations. Genome Res. (2017) 27:885-96. doi: $10.1101 /$ gr.217117.116

31. Huo N, Zhu T, Altenbach S, Dong L, Wang Y, Mohr T, et al. Dynamic evolution of $\alpha$-gliadin prolamin gene family in homeologous genomes of hexaploid wheat. Sci Rep. (2018) 8:5181. doi: 10.1038/s41598-018-23570-5

32. Huo N, Zhang S, Zhu T, Dong L, Wang Y, Mohr T, et al. Gene duplication and evolution dynamics in the homeologous regions harboring multiple prolamin and resistance gene families in hexaploid wheat. Front Plant Sci. (2018) 9:673. doi: 10.3389/fpls.2018.00673

33. Smulders MJM, Jouanin A, Gilissen LJWJ. Gluten genomics in relation to editing coeliac disease epitopes. In: Proceedings of the 32nd Meeting of the Working Group on Prolamin Analysis and Toxicity, Koehler P, editors. Ayr (2019). Pp. 101-8. ISBN 978-3-00-062148-2. Available online at: www.wgpat. com/proceeding_32nd_web.pdf\#page $=102$

34. Salentijn EMJ, Goryunova SV, Bas N, Van der Meer IM, Padioleau I, Gilissen LJWJ, et al. Tetraploid and hexaploid wheat varieties reveal large differences in expression of alpha-gliadins from homoeologous Gli-2 loci. BMC Genomics. (2009) 10:48. doi: 10.1186/1471-2164-10-48

35. Sollid LM, Tye-Din JA, Qiao SW, Anderson RP, Gianfrani C, Koning F. Update 2020: nomenclature and listing of celiac disease-relevant gluten epitopes recognized by CD4+ T cells. Immunogenetics. (2020) 72:85-8. doi: 10.1007/s00251-019-01141-w

36. Vader W, Kooy Y, van Veelen P, de Ru A, Harris D, Benckhuijsen W, et al. The gluten response in children with celiac disease is directed toward multiple gliadin and glutenin peptides. Gastroenterology. (2002) 122:172937. doi: 10.1053 /gast.2002.33606

37. Camarca A, Anderson RP, Mamone G, Fierro O, Facchiano A, Costantini S, et al. Intestinal $\mathrm{T}$ cell responses to gluten peptides are largely heterogeneous: implications for a peptide-based therapy in celiac disease. J Immunol. (2009) 182:4158-66. doi: 10.4049/jimmunol.0803181

38. Mitea C, Salentijn EM, Van Veelen P, Goryunova SV, van der Meer IM, Van Den Broeck HC, et al. A universal approach to eliminate antigenic properties of alpha-gliadin peptides in celiac disease. PLoS ONE. (2010) 5:e15637. doi: 10.1371/journal.pone.0015637

39. Mäki M, Mustalahti K, Kokkonen J, Kulmala P, Haapalahti M, Karttunen T, et al. Prevalence of celiac disease among children in Finland. N Engl J Med. (2003) 348:2517-24. doi: 10.1056/NEJMoa021687

40. Rewers M. Epidemiology of celiac disease: what are the prevalence, incidence, and progression of celiac disease? Gastroenterology. (2005) 128:S47-51. doi: 10.1053/j.gastro.2005.02.030

41. Catassi C, Fasano A. Coeliac disease: the debate on coeliac disease screening-are we there yet? Nat Rev Gastroenterol Hepatol. (2014) 11:457. doi: 10.1038/nrgastro.2014.119

42. Vriezinga SL, Schweizer JJ, Koning F, Mearin ML. Coeliac disease and glutenrelated disorders in childhood. Nat Rev Gastroenterol Hepatol. (2015) 12:527. doi: 10.1038/nrgastro.2015.98 
43. Van Herpen TW, Goryunova SV, van der Schoot J, Mitreva M, Salentijn E, Vorst $\mathrm{O}$, et al. Alpha-gliadin genes from the A, B, and D genomes of wheat contain different sets of celiac disease epitopes. BMC Genomics. (2006) 7:1. doi: 10.1186/1471-2164-7-1

44. Salentijn EM, Mitea DC, Goryunova SV, van der Meer IM, Padioleau I, Gilissen LJ, et al. Celiac disease T-cell epitopes from gammagliadins: immunoreactivity depends on the genome of origin, transcript frequency, and flanking protein variation. BMC Genomics. (2012) 13:277. doi: 10.1186/1471-2164-13-277

45. Boukid F, Mejri M, Pellegrini N, Sforza S, Prandi B. How looking for celiacsafe wheat can influence its technological properties. Compr Rev Food Sci Food Saf. (2017) 16:797-807. doi: 10.1111/1541-4337.12288

46. Jouanin A, Gilissen LJWJ, Boyd LA, Cockram J, Leigh FJ, Wallington EJ, et al. Food processing and breeding strategies for coeliac-safe and healthy wheat products. Food Res Int. (2018) 110:11-21. doi: 10.1016/j.foodres.2017.04.025

47. Rustgi S, Shewry P, Brouns F, Deleu LJ, Delcour JA. Wheat seed proteins: factors influencing their content, composition, and technological properties, and strategies to reduce adverse reactions. Compr Rev Food Sci Food Safety. (2019) 18:1751-69. doi: 10.1111/1541-4337.12493

48. García-Molina MD, Muccilli V, Saletti R, Foti S, Masci S, Barro F. Comparative proteomic analysis of two transgenic low-gliadin wheat lines and non-transgenic wheat control. J Proteomics. (2017) 165:102-12. doi: 10.1016/j.jprot.2017.06.010

49. Ribeiro M, Nunes FM, Rodriguez-Quijano M, Carrillo JM, Branlard G, Igrejas G. Next-generation therapies for celiac disease: the glutentargeted approaches. Trends Food Sci Technol. (2018) 75:56-71. doi: 10.1016/j.tifs.2018.02.021

50. Van den Broeck HC, van Herpen TW, Schuit C, Salentijn EM, Dekking L, Bosch D, et al. Removing celiac disease-related gluten proteins from bread wheat while retaining technological properties: a study with Chinese Spring deletion lines. BMC Plant Biol. (2009) 9:41. doi: 10.1186/1471-2229-9-41

51. Krasileva KV, Vasquez-Gross HA, Howell T, Bailey P, Paraiso F, Clissold L, et al. Uncovering hidden variation in polyploid wheat. Proc Natl Acad Sci USA. (2017) 114:E913-21. doi: 10.1073/pnas.1619268114

52. Gil Humanes J, Pistón F, Hernando A, Alvarez JB, Shewry PR, Barro F. Silencing of $\gamma$-gliadins by RNA interference (RNAi) in bread wheat. J Cereal Sci. (2008) 48:565-8. doi: 10.1016/j.jcs.2008.03.005

53. Becker D, Wieser H, Koehler P, Folck A, Mühling KH, Zörb C. Protein composition and techno-functional properties of transgenic wheat with reduced $\alpha$-gliadin content obtained by RNA interference. J Appl Bot Food Qual. (2012) 85:23. Available online at: https://ojs.openagrar.de/.../2371

54. Altenbach SB, Chang HC, Yu XB, Seabourn BW, Green PH, Alaedini A. Elimination of omega-1, 2 gliadins from bread wheat (Triticum aestivum) flour: effects on immunogenic potential and end-use quality. Front Plant Sci. (2019) 10:580. doi: 10.3389/fpls.2019.00580

55. Shan Q, Wang Y, Li J, Zhang Y, Chen K, Liang Z, et al. Targeted genome modification of crop plants using a CRISPR-Cas system. Nat Biotechnol. (2013) 31:686. doi: 10.1038/nbt.2650

56. Zhou H, Liu B, Weeks DP, Spalding MH, Yang B. Large chromosomal deletions and heritable small genetic changes induced by CRISPR/Cas9 in rice. Nucleic Acids Res. (2014) 42:10903-14. doi: 10.1093/nar/gku806

57. Barro F, Iehisa JC, Giménez MJ, García-Molina MD, Ozuna CV, Comino I, et al. Targeting of prolamins by RNAi in bread wheat: effectiveness of seven silencing-fragment combinations for obtaining lines devoid of coeliac disease epitopes from highly immunogenic gliadins. Plant Biotechnol J. (2016) 14:986-96. doi: 10.1111/pbi.12455

58. Altenbach SB, Chang HC, Rowe MH, Yu XB, Simon-Buss A, Seabourn BW, et al. Reducing the immunogenic potential of wheat flour: silencing of alpha gliadin genes in a U.S. Wheat cultivar. Front Plant Sci. (2020) 11:20. doi: 10.3389/fpls.2020.00020

59. Li W, Zhang P, Fellers JP, Friebe B, Gill BS. Sequence composition, organization, and evolution of the core Triticeae genome. Plant J. (2004) 40:500-11. doi: 10.1111/j.1365-313X.2004.02228.x

60. Wicker T, Mayer KF, Gundlach H, Martis M, Steuernagel B, Scholz U, et al. Frequent gene movement and pseudogene evolution is common to the large and complex genomes of wheat, barley, and their relatives. Plant Cell. (2011) 23:1706-18. doi: 10.1105/tpc.111.086629
61. Jupe F, Witek K, Verweij W, Sliwka J, Pritchard L, Etherington GJ, et al. Resistance gene enrichment sequencing ( $\mathrm{R}$ en $\mathrm{S}$ eq) enables reannotation of the NB-LRR gene family from sequenced plant genomes and rapid mapping of resistance loci in segregating populations. Plant J. (2013) 76:530-44. doi: $10.1111 /$ tpj.12307

62. Endo TR, Gill BS. The deletion stocks of common wheat. J Heredity. (1996) 87:295-307. doi: 10.1093/oxfordjournals.jhered.a023003

63. International Wheat Genome Sequencing Consortium. Shifting the limits in wheat research and breeding using a fully annotated reference genome. Science. (2018) 361:eaar7191. doi: 10.1126/science.aar7191

64. Hindson BJ, Ness KD, Masquelier DA, Belgrader P, Heredia NJ, Makarewicz AJ, et al. High-throughput droplet digital PCR system for absolute quantitation of DNA copy number. Anal Chem. (2011) 83:8604-10. doi: 10.1021/ac202028g

65. Collier R, Dasgupta K, Xing YP, Hernandez BT, Shao M, Rohozinski D, et al. Accurate measurement of transgene copy number in crop plants using droplet digital PCR. Plant J. (2017) 90:1014-25. doi: 10.1111/tpj.13517

66. Sears ER. Nullisomic-tetrasomic combinations in hexaploid wheat. In: Riley R, Lewis KR, editors. Chromosome Manipulations and Plant Genetics. Boston, MA: Springer (1966). p. 29-45.

67. Metakovsky EV, Novoselskaya AY, Sozinov AA. Genetic analysis of gliadin components in winter wheat using two-dimensional polyacrylamide gel electrophoresis. Theor Appl Genet. (1984) 69:31-7. doi: 10.1007/BF00262533

68. Brown JWS, Flavell RB. Fractionation of wheat gliadin and glutenin subunits by two-dimensional electrophoresis and the role of group 6 and group 2 chromosomes in gliadin synthesis. Theor Appl Genet. (1981) 59:349-59. doi: $10.1007 /$ BF00276448

69. Van den Broeck HC, De Jong HC, Salentijn EMJ, Dekking L, Bosch D, Hamer RJ, et al. Presence of celiac disease epitopes in modern and old hexaploid wheat varieties: wheat breeding may have contributed to increased prevalence of celiac disease. Theor Appl Genet. (2010) 121:1527-39. doi: 10.1007/s00122-010-1408-4

70. Van den Broeck HC, Gilissen LJ, Smulders MJ, van der Meer IM, Hamer RJ. Dough quality of bread wheat lacking $\alpha$-gliadins with celiac disease epitopes and addition of celiac-safe avenins to improve dough quality. J Cereal Sci. (2011) 53:206-16. doi: 10.1016/j.jcs.2010.12.004

71. Hurkman WJ, Tanaka CK, Vensel WH, Thilmony R, Altenbach SB. Comparative proteomic analysis of the effect of temperature and fertilizer on gliadin and glutenin accumulation in the developing endosperm and flour from Triticum aestivum L. cv. Butte 86. Proteome Sci. (2013) 11:8. doi: 10.1186/1477-5956-11-8

72. Dziuba M, Nałecz D, Szerszunowicz I, Waga J. Proteomic analysis of wheat $\alpha /$ A-and $\beta$-Gliadins. Czech J Food Sci. (2014) 32:437-42. doi: 10.17221/600/2013-CJFS

73. Vensel WH, Tanaka CK, Altenbach SB. Protein composition of wheat gluten polymer fractions determined by quantitative two-dimensional gel electrophoresis and tandem mass spectrometry. Proteome Sci. (2014) 12:8. doi: 10.1186/1477-5956-12-8

74. Van den Broeck HC, Cordewener JH, Nessen MA, America AH, Van der Meer IM. Label free targeted detection and quantification of celiac disease immunogenic epitopes by mass spectrometry. J Chromatography A. (2015) 1391:60-71. doi: 10.1016/j.chroma.2015.02.070

75. Colgrave ML, Goswami H, Byrne K, Blundell M, Howitt CA, Tanner GJ. Proteomic profiling of 16 cereal grains and the application of targeted proteomics to detect wheat contamination. J Proteome Res. (2015) 4:2659-68. doi: 10.1021/acs.jproteome.5b00187

76. Schalk K, Lang C, Wieser H, Koehler P, Scherf KA. Quantitation of the immunodominant 33-mer peptide from $\alpha$-gliadin in wheat flours by liquid chromatography tandem mass spectrometry. Sci Rep. (2017) 7:45092. doi: 10.1038/srep45092

77. Schalk K, Koehler P, Scherf KA. Targeted liquid chromatography tandem mass spectrometry to quantitate wheat gluten using well-defined reference proteins. PLoS ONE. (2018) 13:e0192804. doi: 10.1371/journal.pone.0192804

78. Boukid F, Prandi B, Faccini A, Sforza S. A complete mass spectrometry (MS)based peptidomic description of gluten peptides generated during in vitro gastrointestinal digestion of durum wheat: implication for celiac disease. $J$ Am Soc Mass Spectrom. (2019) 30:1481-90. doi: 10.1007/s13361-019-02212-8 
79. Alves TO, D'Almeida CTS, Scherf KA, Ferreira MSL. Modern approaches in the identification and quantification of immunogenic peptides in cereals by LC-MS/MS. Front Plant Sci. (2019) 10:1470. doi: 10.3389/fpls.2019.01470

80. Lexhaller B, Colgrave ML, Scherf KA. Characterization and relative quantitation of wheat, rye, and barley gluten protein types by liquid chromatography-tandem mass spectrometry. Front Plant Sci. (2019) 10:1530. doi: 10.3389/fpls.2019.01530

81. Van den Broeck HC, America AH, Smulders MJ, Bosch D, Hamer RJ, Gilissen LJ, et al. A modified extraction protocol enables detection and quantification of celiac disease-related gluten proteins from wheat. J Chromatogr B. (2009) 877:975-82. doi: 10.1016/j.jchromb.2009.02.035

82. Bose U, Broadbent JA, Byrne K, Hasan S, Howitt CA, Colgrave ML. Optimisation of protein extraction for in-depth profiling of the cereal grain proteome. J Proteomics. (2019) 197:23-33. doi: 10.1016/j.jprot.2019.02.009

83. Londono DM, Smulders MJ, Visser RG, Gilissen LJ, Hamer RJ. Development of a standard test for dough-making properties of oat cultivars. J Cereal Sci. (2014) 59:56-61. doi: 10.1016/j.jcs.2013.10.007

84. Londono DM, Smulders MJ, Visser RG, Gilissen LJ, Hamer RJ. Effect of kilning and milling on the dough-making properties of oat flour. LWT-Food Sci Technol. (2015) 63:960-5. doi: 10.1016/j.lwt.2015.04.033

85. Pistón F, Gil-Humanes J, Rodríguez-Quijano M, Barro F. Down-regulating $\gamma$-gliadins in bread wheat leads to non-specific increases in other gluten proteins and has no major effect on dough gluten strength. PLOS ONE. (2011) 6:e24754. doi: 10.1371/journal.pone.0024754

86. Spaenij-Dekking L, Kooy-Winkelaar Y, van Veelen P, Drijfhout JW, Jonker $\mathrm{H}$, van Soest L, et al. Natural variation in toxicity of wheat: potential for selection of non-toxic varieties for celiac disease patients. Gastroenterology. (2005) 129:797-806. doi: 10.1053/j.gastro.2005.06.017

87. Gil-Humanes J, Pistón F, Altamirano-Fortoul R, Real A, Comino I, Sousa C, et al. Reduced-gliadin wheat bread: an alternative to the gluten-free diet for consumers suffering gluten-related pathologies. PLoS ONE. (2014) 9:e90898. doi: 10.1371/journal.pone.0090898

88. Gil-Humanes J, Pistón F, Barro F, Rosell CM. The shutdown of celiac disease-related gliadin epitopes in bread wheat by RNAi provides flours with increased stability and better tolerance to over-mixing. PLoS ONE. (2014) 9:e91931. doi: 10.1371/journal.pone.0091931

89. Ozuna CV, Barro F. Safety evaluation of transgenic low-gliadin wheat in sprague dawley rats: an alternative to the gluten free diet with no subchronic adverse effects. Food Chem Toxicol. (2017) 107:176e185. doi: 10.1016/j.fct.2017.06.037

90. Haro C, Villatoro M, Vaquero L, Pastor J, Giménez MJ, Ozuna CV, et al. The dietary intervention of transgenic low-gliadin wheat bread in patients with non-celiac gluten sensitivity (NCGS) showed no differences with gluten free diet (GFD) but provides better gut microbiota profile. Nutrients. (2018) 10:1964. doi: 10.3390/nu10121964

91. Zong Y, Wang Y, Li C, Zhang R, Chen K, Ran Y, et al. Precise base editing in rice, wheat and maize with a Cas9-cytidine deaminase fusion. Nat Biotechnol. (2017) 35:438. doi: 10.1038/nbt.3811

92. Eid A, Alshareef S, Mahfouz MM. CRISPR base editors: genome editing without double-stranded breaks. Biochem J. (2018) 475:1955-64. doi: 10.1042/BCJ20170793

93. Sun $\mathrm{Y}$, Zhang $\mathrm{X}$, Wu C, He Y, Ma Y, Hou H, et al. Engineering herbicide-resistant rice plants through CRISPR/Cas9-mediated homologous recombination of acetolactate synthase. Mol Plant. (2016) 9:628-31. doi: 10.1016/j.molp.2016.01.001

94. Puchta H. Using CRISPR/Cas in three dimensions: towards synthetic plant genomes, transcriptomes and epigenomes. Plant J. (2016) 87:5-15. doi: $10.1111 /$ tpj. 13100

95. Lin Q, Zong Y, Xue C, Wang S, Jin S, Zhu Z, et al. Prime genome editing in rice and wheat. Nat. Biotechnol. (2020). doi: 10.1038/s41587-020-0455-X. [Epub ahead of print].

96. Galili G, Levy AA, Feldman M. Gene-dosage compensation of endosperm proteins in hexaploid wheat Triticum aestivum. Proc Natl Acad Sci USA. (1986) 83:6524-8. doi: 10.1073/pnas.83.17.6524

97. Kim CY, Quarsten H, Bergseng E, Khosla C, Sollid LM. Structural basis for HLA-DQ2-mediated presentation of gluten epitopes in celiac disease. Proc Natl Acad Sci USA. (2004) 101:4175-9. doi: 10.1073/pnas.0306885101
98. Broughton SE, Petersen J, Theodossis A, Scally SW, Loh KL, Thompson A, et al. Biased $\mathrm{T}$ cell receptor usage directed against human leukocyte antigen DQ8-restricted gliadin peptides is associated with celiac disease. Immunity. (2012) 37:611-21. doi: 10.1016/j.immuni.2012.07.013

99. Petersen J, van Bergen J, Loh KL, Kooy-Winkelaar Y, Beringer DX, Thompson A, et al. Determinants of gliadin-specific T cell selection in celiac disease. J Immunol. (2015) 194:6112-22. doi: 10.4049/jimmunol.1500161

100. Directive 2001/18/EC. Directive 2001/18/EC of the European Parliament and of the Council of 12 March 2001 on the Deliberate Release Into the Environment Of Genetically Modified Organisms And Repealing Council Directive 90/220/EEC - Commission Declaration. Official J. (2001). p. 1-39.

101. European Court of Justice [ECJ]. Judgement of the Court in Case C-528/16. (2018). Available online at: http://curia.europa.eu/juris/documents.jsf?num= C-528/16 (accessed July 2, 2018).

102. European Court of Justice [ECJ]. Opinion of Advocate General Bobek in Case C-528/16. (2018). Available online at: http://curia.europa.eu/juris/ documents.jsf?num $=\mathrm{C}-528 / 16$ (accessed January 8,2018 ).

103. McDougall P. The Cost and Time Involved in the Discovery, Development and Authorisation of a New Plant Biotechnology Derived Trait: A Consultancy Study for Crop Life International. (2011). Available online at: https://croplife. org/wp-content/uploads/pdf_files/Getting-a-Biotech-Crop-to-MarketPhillips-McDougall-Study.pdf (accessed November 7, 2019).

104. Jouanin A, Boyd LA, Visser RGF, Smulders MJM. Development of wheat with hypoimmunogenic gluten obstructed by the gene editing policy in Europe. Front. Plant Sci. (2018) 9:1523. doi: 10.3389/fpls.2018.01523

105. Jouanin A, Smulders MJM. Gene-edited 'Gluten-Safe' wheat, and policy issues regarding new plant breeding techniques. In: Dürnberger C, Pfeilmeier S, Schleissing S, editors. Genome Editing in Agriculture: Between Precaution and Responsibility. TTN-Studien. Baden-Baden: Nomos (2019). p. 7-61.

106. Schenk MF, Fischer ARH, Frewer LJ, Gilissen LJWJ, Jacobsen E, Smulders MJM. The influence of perceived benefits on acceptance of GM applications for allergy prevention. Health Risk Soc. (2008) 10:263-82. doi: $10.1080 / 13698570802160947$

107. Schenk MF, van der Maas MP, Smulders MJM, Gilissen LJWJ, Fischer AHR, van der Lans IA, et al. Consumer attitudes towards hypoallergenic apples that alleviate mild apple allergy. Food Qual Prefer. (2011) 22:83-91. doi: 10.1016/j.foodqual.2010.08.003

108. Saturni L, Ferretti G, Bacchetti T. The gluten-free diet: safety and nutritional quality. Nutrients. (2010) 2:16-34. doi: 10.3390/nu2010016

109. Codex Alimentarius Commission. Codex Alimentarius International Food Standard Webpage. (2014). Available online at: www.codexalimentarius.net

110. Bruins Slot ID, Bremer MGEG, van der Fels I, Hamer RJ. Evaluating the performance of gluten ELISA test kits: the numbers do not tell the tale. Cereal Chem. (2015) 92:513-21. doi: 10.1094/CCHEM-07-14-0166-R

111. Martínez-Esteso MJ, Nørgaard J, Brohée M, Haraszi R, Maquet A, O'Connor G. Defining the wheat gluten peptide fingerprint via a discovery and targeted proteomics approach. J Proteomics. (2016) 147:156-68. doi: 10.1016/j.jprot.2016.03.015

112. Koning F. Celiac disease: quantity matters. Semin Immunopathol. (2012) 34:541-9. doi: 10.1007/s00281-012-0321-0

113. Moehs CP, Austill WJ, Holm A, Large TA, Loeffler D, Mullenberg J, et al. Development of decreased-gluten wheat enabled by determination of the genetic basis of lys3a barley. Plant Physiol. (2019) 179:1692-703. doi: $10.1104 /$ pp.18.00771

Conflict of Interest: The authors declare that the research was conducted in the absence of any commercial or financial relationships that could be construed as a potential conflict of interest.

Copyright (๑ 2020 Jouanin, Gilissen, Schaart, Leigh, Cockram, Wallington, Boyd, van den Broeck, van der Meer, America, Visser and Smulders. This is an open-access article distributed under the terms of the Creative Commons Attribution License (CC $B Y)$. The use, distribution or reproduction in other forums is permitted, provided the original author(s) and the copyright owner(s) are credited and that the original publication in this journal is cited, in accordance with accepted academic practice. No use, distribution or reproduction is permitted which does not comply with these terms. 